\title{
Improvement of anthrone method of determination of the content of soluble carbohydrate in nodes of tillering of plants of winter wheat for assessment of sowings during wintering
}

\author{
M. Lytvynenko, \\ Academician of NAAS, Doctor of Agricultural Sciences \\ P. Feoktistov, \\ Ph.D. in Biology \\ D. Blyshchyk, \\ Ph.D. in Geography \\ S. Havrylov
}

Plant-Breeding and Genetic Institute - National Center of Seed and Cultivar Investigation

The purpose. Perfecting procedure of determination of the content of carbohydrate in nodes of tillering of plants of winter wheat by anthrone method in view of biology of the crop, features of their selection, storage and fixation. Methods. The content of carbohydrate was determined with anthrone method. Assessment of cultivars was carried out in field conditions in 2013 and 2014 by biochemical and agrobiological methods. Results. Dynamics is studied of accumulation of carbohydrate, formation of frost resistance and growth of plants of winter wheat depending on favorable weather conditions for training. Efficiency is proved of the offered developments of anthrone method for determination of the content of carbohydrate in nodes of tillering of plants of winter wheat. Conclusions. Use of the improved technique for determination of the content of carbohydrate with simultaneous fixation of critical temperature of frost killing and phase of growth allows assessing general state of plants of winter wheat and predicting perspectives of their further wintering in view of long-term forecasts of weather environment.

Key words: winter wheat, carbohydrate, nodes of tillering, training, frost resistance, wintering, weather environment.

Changes of agrometeorological conditions in the autumn-winter period of the southern Ukraine led to the fact that significant portions of winter wheat modern varieties cannot form inherent them genetically determined frost resistance level. In the interaction of "plants - environment," autumn vegetative period of bread winter wheat plants is an essential stage that responsible for their biological potential. Since the winter crop conditions after the termination of autumn vegetation have an important role in their wintering and hardening to unfavorable meteorological conditions in winter period is one of the main processes, which provides the plant's survival and future harvest [1].

First of all, on the basis of plant's hardening is the metabolism of natural substances of carbohydrate nature. Accumulation of sugar in the winter crops plants during hardening period is an essential factor that largely determines the plant's resistant to winter stresses and of winter hardiness conditions level.

Given the importance accumulation of sugar winter crops plants during the hardening, scientists came to the conclusion about the possibility of the data about the sugars content into their tempering quality indicator, as well as frost and winter hardiness is [2,3]. At the same time, some authors are close links between content sugars into plants of bread winter wheat in front of the winter and their frost $[4,5]$.

According to O.I. Kolosha [6] a content of soluble reducing sugars at the tillering nodes of wheat plants at the end of autumn vegetation isn't always an indicator of frost resistance. Sugars increase frost resistance but do not define its during small low temperatures. However, at temperatures that plants get to the extremely critical conditions, there is a clear correspondence between frost resistance and the content of the reducing sugar's sum. Thus, the sugar content, which characterizes the level of hardening, should be analyzed in dynamics under conditions of functional capacity of low temperatures. 
There are many methods of the determining sugar content, based on their physical or chemical properties: refractometric, areometric, polarimetric, chromatographic, and chemical [7]. Using certain method depends on the object of research, the content of water and sugary substances. There are various types of carbohydrates in the cells of wheat plants tillering nodes. Therefore, for the determining their content, the most proper are using the chemical methods because they give an opportunity to define with high accuracy in fresh and fixed plant material as well. Chemical methods are classified depending on which reagent is used (permanganate, anthronic and others). For instance, the method according to State Standart 26176-93 is used for the sugar content in the feed [8], but it provides for its determination in the dried product in natural conditions (hay, mixed fodder) or preserved (haylage, silage) ones. In laboratory practice, Bertrand method and its modification by L.Voznesenskiy [9] are often used, which is based on the copper sulfate recovery to cuprous oxide and athronic method of determining sugar content [10]. However, these methods do not work as a method of describing the peculiarities of selection, storage, and fixation of samples, that's why they are not acceptable for manipulation with the winter wheat plants, especially during the sampling in the winter period, which has its specificity [11].

The sugar content at the tillering nodes of wheat plants needs to keep samples in natural (native) condition until the analysis. Plants should be analyzed fresh, immediately after the sampling, or if there's a lack of such opportunity, fixed and dried state for minimum losses of soluble carbohydrates. Determination of the node tillering is obligatory, that mostly characterizes the soluble carbohydrates content in the plant tissues, bordering to the apical cone. It is necessary to take into account the minimum depth of a node tillering occurrence because it gives the opportunity to get rid of the necessity for lightening of the hydrolysate solution through chlorophyll coloring.

The aim of research. Improvement of the methodology of carbohydrates content in the tillering nodes of winter crops by including the biology of a crop and peculiarities of their selection, storage, and fixation for increasing the accuracy and truthfulness of analysis.

Material and methods of research. Selection of plants from the field in bunches was used in order to assess the dynamics and the level of developed frost resistance [12].

For studying the carbohydrates content at the tillering nodes of plants from field crops dig out (in the presence of frozen soil) or cut down (if the soil is frozen) in three spots on the diagonal area or field (up to 50 hectares) and form the beams 30/50 plants in each. If the field square is more than 50 hectares, it should be divided into several plots and select three samples from each one. Each sample is labeled, the name of the institute, field's number, the name of the variety, and selection date are indicated on a label. If the air temperature is below $-10^{\circ} \mathrm{C}$, selection of samples is not recommended. Samples are transported in plastic bags or cotton and paper bags, at temperatures close to the temperature of soil on a depth of tillering nodes occurrence. Delivery time to the lab in such conditions should not exceed 24 hours. During the winter time, samples are selected and analyzed monthly, and if it's necessary, (e.g. sudden changes in temperatures, lack of snow cover, etc.) - every decade. The soil is shaken from plant samples off. Samples are washed in water, root system and above-ground biomass are cut with scissors so the tillering nodes are reminded in height from 2,0 to $2,5 \mathrm{~cm}$, and dead skin tissue is removed. Prepared tillering nodes are fixed in a thermostat or drying closet and are wrapped in cotton fabric or gauze, watered in distilled water during 15 minutes at a temperature of $105^{\circ} \mathrm{C}$ and there are dried at a maximum temperature of $45^{\circ} \mathrm{C}$ to an air-dry condition for avoiding dextrinizing of soluble carbohydrates. Dried material is shredded on the mill type "Piruet" or in a mortar with pestle and is kept until the analysis in glass jars or test tubes with plugs.

A sample of plant material weigh $20 \mathrm{mg}$ in two replications are weighted up to $0,001 \mathrm{~g}$, put in chemical test tubes, poured $10 \mathrm{~cm}$ distilled water, and warmed by the temperature of $60^{\circ} \mathrm{C}$. The tubes are put into thermostat with a temperature $60^{\circ} \mathrm{C}$ for 30 minutes and their contents are stirred occasionally by glass rods. After finishing ? extracting process content the content of the test tubes is filtered through the glass watering can with filter paper to the measuring flask with $100 \mathrm{~cm}^{3}$ volume. Glass road is poured on the filter paper. Sediment is poured by a small amount of warm distilled water. After cooling in the flask add distilled water to risks and thoroughly mixed. The original soluble carbohydrate extract is got. 
Sediment from the filter after removal of soluble carbohydrates is thoroughly washed through the hole using the pipette by the solution of sulfuric acid (molar concentration is $0.25 \mathrm{~mole} / \mathrm{dm}^{\prime}$ ) into the test tube, where the extraction was conducted for receiving a hydrolysate of hydrolyzed carbohydrates. The total volume of solution in test tubes should be $10 \mathrm{~cm}$. Tubes in mini tripods are put in the boiling water bath for 30 minutes and a draught cupboard is switched on at the same time. The content of test tubes is periodically stirred by glass rods. Then it is filtered through glass watering can and paper filter into the $100 \mathrm{~cm}^{3}$ volumetric flask. Sediment on the filter is washed with distilled water after cooling the filtrate. Liquid volume in a retort is brought to marking by distilled water and thoroughly stirred. Hydrolyzate of the hydrolyzed carbohydrates is received. Extract and hydrolysate are stored no more than 24 hours in the refrigerator.

The color of extract solutions and hydrolyzate is conducted in the heat-resistant test tubes. The volume of $0.5 \mathrm{~cm}$ of the extract and hydrolyzate are poured into the heat-resistant tubes in two repetitions by dispenser or pipette and $2.5 \mathrm{~cm}$ of anthronic reagent is put carefully and quickly. A standard glucose solution is poured separately into $0.5 \mathrm{~cm}$ tubes with adding $2,5 \mathrm{~cm}$ of anthronic reagent in each. To control the reagents, zero solution is made $(0.5 \mathrm{~cm}$ water with the adding of $2,5 \mathrm{~cm}$ of anthronic reagent). The content of test tubes is thoroughly stirred by glass rods. Then they are put in a water bath under switched on bain-marie while stirring the holder with test tubes so that its bottom doesn't touch the bottom of the bain-marie. During the heating water shouldn't get to the test tubes. Coloring lasts 5 minutes at a temperature of $100^{\circ} \mathrm{C}$. After the coloring of solutions, tubes are taken out of the bain-marie, cooled in the water to the room temperature and after 30 minutes the optical density of the standard solution and sampling solutions relative to zero are defined by the wavelength of $630 \mathrm{~nm}$ at spectrophotometer. If solutions are prepared without dilution and have very low optical density measurement, the analysis is repeated by increasing the weighted samples or volume of solutions of extracts, hydrolysates that are used for lightening. If optical density is high, the solutions are diluted by the zero solution before coloring.

Processing the results. Mass fraction of soluble carbohydrates (sugars) in the experimental sample $(\omega)$ is calculated using the formula:

$$
\omega_{1}=\frac{m_{c m} * D_{x} * n * 100}{D_{c m} * m_{0} * 1000}
$$

where $m_{m}$ - the mass of glucose in the standard solution, $50 \mathrm{mg}$;

$D_{i}$ - the optical density in the experimental sample;

$n-$ the dilution of the test sample;

100 - the conversion factor to a percent;

$D_{\text {: }}$ - the absorbance of the standard solution;

$m_{\bullet}$ - a sample, $20 \mathrm{mg}$;

1000 - the conversion factor $\mathrm{mg}$ of glucose to mcg.

Mass fraction of the hydrolysable carbohydrates in the experimental sample $\left(\omega_{l}\right)$ is calculated using the formula:

$$
\omega_{2}=\frac{m_{c m} * D_{x} * n * 100 * 0,9}{D_{c m} * m_{0} * 1000}
$$

where $m_{n}-$ the mass of glucose in the standard solution, $50 \mathrm{mg}$;

$D_{i}$ - the optical density;

$n$ - the dilution of the test sample;

100 - the conversion factor to a percent;

$D_{\sharp}$ - the absorbance of the standard solution;

$\mathrm{m}$ - a sample, $20 \mathrm{mg}$;

100 - the conversion factor $\mathrm{mg}$ glucose to $\mathrm{mcg}$; 
1000 - the conversion factor mcg of glucose to $\mathrm{mg}$.

0.9 - the conversion factor fraction of the soluble carbohydrates to a fraction of hydrolysable carbohydrates.

Soluble mass fraction $\left(\omega_{1}\right)$ and hydrolysable $\left(\omega_{i}\right)$ carbohydrates as a percentage of dry matter are calculated by the formula:

$$
\omega_{1}=\frac{\omega_{p} * 100}{100-\omega_{\partial . n .}}
$$

where $\omega_{p}-$ a mass fraction of soluble carbohydrates in the experimental sample, $\%$;

$\omega_{\text {in }}$ - a moisture content in the test sample, \%;

100 - the conversion factor to a percent.

$$
\omega_{2} \frac{\omega_{n}^{*} 100}{100-\omega_{\partial . n}}
$$

where $\omega_{1}-$ a mass fraction hydrolysable carbohydrates in the experimental sample, \%;

$\omega_{i 1}$ - a moisture content in the test sample, \%;

100 - the conversion factor to a percentage.

The arithmetic mean of the two parallel determinations results was taken as a final test result. The results were calculated to the second decimal place and round off to the first one.

Investigation of the accumulation and usage of carbohydrates in plants tillering nodes of winter wheat in connection with their winter hardiness and improvement of methods for determining the soluble carbohydrates content in plant tissues revealed that the accumulation of soluble carbohydrates in the winter wheat plants in winter time had gradient character.

Therefore, the tillering nodes of the bread winter wheat were cut to length $2.5 \mathrm{~cm}$ from its base for an objective and reliable determination of the soluble carbohydrates [11]. In addition, this part of the tillering node is almost always etiolated, that eliminates the necessity for additional biochemical measures related to the enlightenment of hydrolysate solution through coloring by chlorophyll. Also it was found, that the storage of selected plants, transportation, and preparation for analysis after inactivation of enzyme systems, should take place under a low temperature and take the least amount of time, no more than 1-2 hours.

An example of the results of studies of the sugar accumulation dynamics, the frost resistance, and the crop progress depending on favorable weather conditions of hardening is presented in table 1.

Table 1. Dynamics of the frost resistance, crop progress, and soluble carbohydrates content in the tillering nodes of bread winter wheat plants in favourable (2013) and unfavourable (2014) for

\begin{tabular}{|c|c|c|c|c|c|}
\hline \multirow{2}{*}{ Variety } & \multicolumn{5}{|c|}{ Date of selection } \\
\hline & $31 . X$ & $10 . \mathrm{XI}$ & 20.XI & 30.XI & 10.XII \\
\hline \multicolumn{6}{|l|}{ The 2013 year* } \\
\hline Phase of plant development & 2-3 leaves & $\begin{array}{l}\text { Beginning of } \\
\text { tillering }\end{array}$ & $\begin{array}{l}1-2 \text { stems } \\
\text { of tillering }\end{array}$ & $\begin{array}{l}2 \text { stems of } \\
\text { tillering }\end{array}$ & $\begin{array}{l}2-3 \text { stems } \\
\text { of tillering }\end{array}$ \\
\hline $\begin{array}{l}\text { Sugar, } \% \text { the mass of a dry } \\
\text { matter }\end{array}$ & $20,0 \pm 0,6$ & $17,4 \pm 0,5$ & $14,6 \pm 0,5$ & $29,2 \pm 0,6$ & $54,2 \pm 1,2$ \\
\hline $\begin{array}{l}\text { The critical temperature at a } \\
\text { depth of the tillering node } \\
\text { formation, }{ }^{\circ} \mathrm{C}\end{array}$ & -8 & -10 & -11 & -13 & -17 \\
\hline The 2014 year** $^{* *}$ & & & & & \\
\hline
\end{tabular}
temperature and light conditions of the particular hardening year 


\begin{tabular}{|l|l|l|l|l|l|}
\hline Phase of plant development & $2-3$ leaves & $\begin{array}{l}\text { Beginning of } \\
\text { tillering }\end{array}$ & $\begin{array}{l}1-2 \text { stems } \\
\text { of tillering }\end{array}$ & $\begin{array}{l}2 \text { stems of } \\
\text { tillering }\end{array}$ & $\begin{array}{l}2-3 \text { stems } \\
\text { of tillering }\end{array}$ \\
\hline $\begin{array}{l}\text { Sugar, \% the mass of a dry } \\
\text { matter }\end{array}$ & $19,0 \pm 0,6$ & $20,8 \pm 0,5$ & $25,1 \pm 0,5$ & $23,3 \pm 0,6$ & $31,4 \pm 0,9$ \\
\hline $\begin{array}{l}\text { The critical temperature at a } \\
\text { depth of the tillering node } \\
\text { formation, }{ }^{\circ} \mathrm{C}\end{array}$ & -6 & -8 & -9 & -11 & -13 \\
\hline
\end{tabular}

${ }^{*}$ Sowing date 09.10.2013 p.; ** Sowing date 10.10.2014 p.

Analysis of the dependence of frost resistance from a number of accumulated sugars indicates the presence of a trend of a direct relationship between them. For example, in 2013, there was a gradual decrease in the tillering node sugar content on the background of increase of the winter hardiness. This is due to the fact that the consumption of energy pool on intensive growth processes was taking place on the background of a high average daily air temperatures that were observed in the second decade of November and riches more than 10 ${ }^{\circ} \mathrm{C}$ with the maximum $18,9^{\circ} \mathrm{C}$. Subsequently, the temperatures were decreasing and for nearly 45 days were favorable for the passage of the first phase of hardening, and in December there was a gradual transition through $0{ }^{\circ} \mathrm{C}$, which contributed to the effective passage of the second phase of hardening. It allowed forming a high frost and winter hardiness before significant frosts in late January that reached $-22{ }^{\circ} \mathrm{C}$, which positively reflected on successful wintering and on the future yield.

In 2014 the duration of the favorable temperature and light conditions to the passage of the first phase of hardening was only 14 days. As is the case with 2013 year significant correlation between the level of sugars and frost resistance of winter wheat plants to the transition temperature at $0{ }^{\circ} \mathrm{C}$ wasn't observed. The critical temperature of freezing at a depth of the tillering node formation was only $-12{ }^{\circ} \mathrm{C}$ due to the insufficient duration of the first phase of hardening to the time of a significant frost occurrence that reached $-16^{\circ} \mathrm{C}$ in December.

\section{Conclusions}

Thanks to studying the dynamics of the soluble carbohydrates content in the tillering nodes of winter wheat plants with simultaneous determination of the critical temperature of freezing in the field conditions of the particular year it is possible not only to adjust and assess the general condition of winter crops, but also to predict their future prospects of wintering on the long-term weather forecasts. Recommended improvements to the methodology for determining the carbohydrate content in the winter wheat plant tillering nodes by anthrone method allow increasing the cost-effectiveness and informativeness of a research by taking into consideration the biology of the crop, features of selection, storage, and fixation of samples.

\section{References}

1. Polevoj A.N. Modelirovanie formirovanija zimostojkosti rastenijami ozimoj pshenicy/A.N. Polevoj, D.V. Blyshhik, P.A. Feoktistov//Problemy jekologicheskogo monitoringa i modelirovanija jekosistem. — XXVI. — №1. Moskva, 2015. - S. 28-48.

2. Kruzhilin A.S. Nakoplenie Saharov u ozimyh "dvuruchek" i jarozyh pshenic pri ponizhennyh temperaturah/A.S. Kruzhilin. - Fiziol. rast., 1963, T. 10. - Vyp. 3. - S. 374-379.

3. Poltarev E.M. Analiz vzaimosvjazi mezhdu soderzhaniem rastvorimyh uglevodov i kriticheskimi temperaturami u zlakovyh kul'tur v period zimovki/E.M. Poltarev, V.D. Zolochevskaja//Selekcija i semenovodstvo: Mezhved. temat. nauchn. sb. — K.: Urozhaj, 1978. - Vyp. 24. - S. 61-68.

4. Musich V.N. Kolichestvennoe soderzhanie i kachestvennyj sostav saharov u rastenij ozimoj pshenicy pri zakalivanii/V.N. Musich//Rost i ustojchivost' rastenij. — K.: Naukova dumka, 1967. — Vyp.3. - S. 210-214.

5. Orlov V.M. O zimostojkosti ozimoj pshenicy/V.M. Orlov//Donskoj zonal'nyj NII SH., 1978. — Vyp.10. — S. 63-68.

6. Kolosha O.I. Fiziologicheskie osnovy morozostojkosti ozimyh zernovyh kul'tur/O.I. Kolosha//Nauchnye trudy VASHNIL: Metody i prijomy povyshenija zimostojkosti zernovyh kul'tur. — M.: Kolos, 1975. — S. 294-306. 
7. Metody biohimicheskogo issledovanija rastenij/A.I. Ermakov, V.V. Arasimovich, N.P. Jarosh i dr. - 3-e izd., pererab. i dop. — Leningrad: Agropromizdat, LO, 1987. - 430s.

8. Korma, kombikorma. Metody opredelenija rastvorimyh i legkogidrolizuemyh uglevodov: GOST 26176-93. - M.: Gosstandart, 1993. - 17 s.

9. Opredelenie saharov po obescvechivaniju zhidkosti Fellinga/V.L. Voznesenskij, G.I. Gorbacheva, T.P. Shtan'ko, L.A. Filippova//Fiziologija rastenij. — 1962. — T. 9, № 2. — S. 255-256.

10. Praktikum po obshhej biohimii: Ucheb. posobie dlja studentov him. special'nostej ped. in-tov/Pod obshh. red. Ju.B. Filippovicha. — M.: «Prosveshhenie», 1975. - 318 s.

11. Metod viznachennja vmistu rozchinnih vuglevodiv u vuzlah kushhinnja ozimoï pshenici: metodichni rekomendaciï/N.I. Rjabchun, V.I. Dolgopolova, V.M. Ivanova, O.M. Chetverik//UAAN, In-t roslinnictva im. V.Ja. Jur'eva. - H., 2006. $-12 \mathrm{~s}$.

12. Feoktistov P.O. Metodologichni principi ocinki ozimoï pshenici na termorezistentnist' $v$ umovah Pivdnja Ukraïni: metodichni rekomendaciï/P.O. Feoktistov, A.K. Ljashok, I.P. Grigorjuk, M.D. Mel'nichuk. — K.: Vidavnichij centr NAU, 2006. - $36 \mathrm{~s}$. 